\title{
Exploring the economic contribution of copyright-intensive industries in Italy
}

\author{
Simone Manfredi ${ }^{1}$, Fabio Nappo ${ }^{1 *}$, Federica Ricci ${ }^{1}$ and Marina Maggioni ${ }^{2}$
}

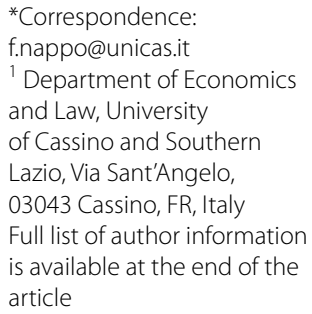

\begin{abstract}
Purpose: In the last few years, a number of studies documented the economic impact of copyright in different national economies. The purpose of this paper is to contribute to increase these studies based on the assess of the economic impact of copyrightintensive industries in Italy.
\end{abstract}

Design/methodology/approach: Consistent with prior studies, this paper attempts to measure the impact of copyright on GDP and employment. In doing so, two different methodologies are applied: (1) WIPO's guidelines "Wipo Guide on surveying the Economic Contribution of the Copyright-Based Industries" and (2) the Ernest \& Young study entitled: "1 er Panorama des Industries Culturelles et Créatives. Au Couer du Rayonnement et de la Competitivité de la France". The selected year for the survey is 2011 . The main source data are collected by statistic databases like Istat, Eurostat and United Nations Statistics Division. The industrial classification starts with the International Standard Industrial Classification suggested in the WIPO Guide and, after the conversion, first in NACE and then in ATECO 2007, we identify the industries and their activities as relevant to copyright-based industries in Italy.

Findings: The results of our analysis support the thesis that copyright has a great impact on the aspects of economic growth, of the labour market and on the country development.

Originality/value: This study compares the classification and the methods used for determination of the economic impact of copyright-intensive industries.

Practical implications: By assessing the economic impact of this sector on Italian GDP, this paper raises awareness about the role and importance of such industries to the Italian economy.

Keywords: Intensive copyright industries, Added value, Employment, Impact copyright

\section{Background}

Introduction

In general, it is a well-known fact that during the passage from an industrial society to a society of information, the elaboration and diffusion of knowledge become extremely important (Chase 1997; Carayannis and Campbell 2011). In this context, copyright takes on an important value, as it represents an incentive instrument to the manufacturers of new knowledge (Lessig 2004).

(c) 2016 Manfredi et al. This article is distributed under the terms of the Creative Commons Attribution 4.0 International License (http://creativecommons.org/licenses/by/4.0/), which permits unrestricted use, distribution, and reproduction in any medium, provided you give appropriate credit to the original author(s) and the source, provide a link to the Creative Commons license, and indicate if changes were made. 
Measuring of the economic impact of a sector, in general, is very important to the neoclassical economy that traditionally focuses on how the use of economic resources may improve the economic benefits of the society.

National economic policies in market economies focus on creating growth in the economy, and the use of sectorial indicators helps explain what industries add to the economy. This is typically done by focusing on the value added to the economy, that is, the increase in wealth resulting from the activity (Picard and Toivonen 2004).

In this perspective, in the last few years, studies focused on explaining the bond that exists between creative industries and economic growth have increased (Idris 2003; Park 2010; Barrowclough and Kozul-Wright 2008; Carayannis 2006, 2009; Del Giudice et al. 2013).

In particular, a number of studies have documented the economic impact of copyright on national economies. In this context, many authors prove how the production of value of copyright industries exceeds that of traditional industries in several countries (Hummel 1989; Scheuch and Holzmüller 1989; Price 1989; Siwek 2004).

A recent contribution has also measured the economic impact of the copyright industries in the USA, Europe and Ukraine using a comparative approach, highlighting the limits of Ukraine legislative measures with regard to the protection of copyright (Dudareva 2013).

The results of these studies have generally been used to study the hypothesis according to which copyright is a powerful source of economic growth, creating jobs and stimulating trade (Van Der Noll and Poort 2011). In this context, many authors conclude how the copyright is a stimulating instrument for economic growth (Towse 2010).

Watt (2013) states that the main objective of copyright protection is to achieve a balance between protection and consumption.

Other experts have concentrated on the impact of copyright industries on Gross Domestic Production (GDP) (Gantchev 2004). For example, an empirical study highlights how intensive copyright industries represent approximately $5.7 \%$ of the GDP of Singapore (Chow and Leo 2005). In the USA, core copyright industries represent approximately $6.44 \%$ of the GDP while the entire field of copyright affects the GDP by approximately $11.05 \%$ (Siwek 2004).

The majority of studies that exist on the importance of copyright industries adopt a basic method that consists in measuring the impact of copyright industries on GDP and on employment.

Some studies only include the export of copyright material (e.g. Siwe and Mosteller 1999); other count the trade balance for copyright and copyright-dependent industries, respectively (Allen Consulting Group 2001).

The works protected by copyright and the industries that take advantage of these works provide an important contribution to the economy of developing countries. Furthermore, the topic of the protection of results of human knowledge through copyright is constantly developed and will continue to do so in the next few years.

In particular, this study will be carried out with reference to the Italian economy, for the year 2011.

In particular, the objective is to provide an answer to the following research question: what is the economic impact of the copyright industries in Italy? 
In order to provide an answer, the paper will be structured as follows:

In the first part, with the obligation of a summary, the main international best practices and the results of similar research will be referred to WIPO and French models. In the second part, two methods will be selected from the ones indicated in the best practices and will be applied to the Italian economy for the year 2011. Finally, as a conclusion, comparisons will be carried out between the two methods selected, with an identification of the main limits and possible future developments of research.

\section{Literature review}

In an analysis of the International best practices, reference is made to the theoretical background issued by the Word Intellectual Property Organization (WIPO), from the Office for Harmonization in the Internal Market and from France.

\section{WIPO model}

As indicated in the introduction, from 2003 the World Intellectual Property Organization (hereinafter also referred to as WIPO) issued guidelines based on international best practices, in order to elaborate methodologies aimed at measuring the economic contribution of the copyright industries on the economic system. These guidelines have been implemented by more than 40 countries.

The methodological approach adopted by the WIPO satisfies a dual requirement: it provides a classification of the industries operating in the field of copyright and quantifies the added value created by each category classified in 39 countries.

The WIPO methodology classifies copyright companies, dividing them between:

1. core industries;

2. non-core industries:

(a) interdependent copyrights;

(b) partial effect copyrights;

(c) support.

In particular, with reference to copyright industries, the core and non-core areas are identified: companies, that deal on an exclusive or priority basis, with the production, distribution, sponsoring and/or the sale of goods and services protected by copyright are classified in the core area; while those in the non-core area include companies connected, on various levels and for different reasons, with organisations connected to the core dominion.

On the basis of this classification, the WIPO guidelines annually measure the economic impact of copyright-based industries, with reference to contribution to the GDP and to employment.

On the basis of the last elaboration available, it can be seen that core copyright industries from all of the 39 countries observed contributed to having an impact on added value with an average quota of $5.26 \%$ and on employment on average of $5.49 \%$.

First of all, it can be seen how, for 2013, contribution to the GDP and to employment in the copyright industries can be attributed more and more to the core dominion, approximately $54.4 \%$ against $45.7 \%$ attributable to the non-core dominion. 
As far as the contribution of copyright industries to employment is concerned, similar proportions can be found: the core dominion, in reality, contributes to approximately $52.4 \%$ of the workforce against $47.4 \%$ of the non-core dominion.

\section{French model}

In France, the economic impact of the culture and creative sector has been the subject of quantitative research, resulting in the Report "Panorama Economique des Industries Culturelles et Creative en France", drawn up for the first time in 2013, in the field of the larger project "France Creative".

The paper originates from the economic policy strategy shared by the French government, related to cultural and creative industries as a concrete opportunity for the future economic development of the country, also by virtue of the Communication of the European commission of 26th September 2012, recommending that the member countries "develop the cultural areas to promote the creation, growth and employment of the European Union".

In this context, France has drawn up an initial report representing the state of the art. In 2011, the cultural and creative industries of France generated a turnover that, on a general level, amounted to more than 74.6 billion Euro.

In particular, approximately $80 \%$ of the total can be attributed to the main sectors of the production chain and the remaining $20 \%$ to indirect sectors.

In general, the methodology adopted by the French report classifies the cultural and creative dominion into nine macro-sectors:

1. graphics and visual art;

2. music;

3. live entertainment;

4. cinema;

5. television;

6. radio;

7. video games;

8. books;

9. press/newspapers/magazines.

These sectors, according to their contribution to the creation, production and distribution of goods and cultural and creative services, are classified in the direct sector (core) or indirect sector (non-core).

With reference, however, to the general impact of companies of the cultural dominion, in 2011, approximately 1.2 million were employed in France, representing almost $5 \%$ of the workforce employed in the entire country.

In particular, it can be seen that $92 \%$ of the employed are classified in the direct sector and only $8 \%$ find employment in indirect sectors. 


\section{Industry level analysis report: European Union}

Due to the objectives defined by the 10-year programme Europe 2020, innovation is one of the basic strategies adopted by the European Union to favour the growth of the country.

In this regard, promotion of the virtuous cycle, that starts with investments in research and development and has a positive effect on the creation of employment, added value and social wellness, is considered extremely important.

The result of this process depends, as highlighted, on a whole range of factors with the efficient management system of intellectual property playing a main role.

In this regard, the Office for Harmonization in the Internal Market (OHIM), represented by the European Observatory on Violation of Intellectual Property and by the European Patents Office, has decided to draw up a study, in collaboration with the European Commission, to measure the economic impact of companies based on intellectual property (here below also indicated as companies from the cultural dominion), with reference to employment and the creation of added value.

The study was carried out on 27 countries from the European Union and included the period ranging from 2008 to 2013.

In the vastness of the reference dominion, the report adopted a classification of the copyright industries, distinguishing them in terms of:

- companies mainly based on brands;

- companies mainly based on patents;

- copyright-based companies; and

- geographic protection based companies.

Starting with aggregate data, it is interesting to carry out stratification with reference to the contribution to added value and to the GDP.

Considering the intensive copyright companies in general, in 2012 they contributed to the generation of a turnover in volume of approximately 4,735,262 million euro, representing $38.56 \%$ of the total GDP of Europe with 27 countries.

In particular, with regard to the impact on added value, the greatest contribution is provided by companies with a strong concentration on brands (33.9\%), following by companies focused on patents (13.9\%) and design (12.8\%). However, the copyrightand geographic protection-based companies affect the GPD of the European Union in a smaller measure, respectively, by 4.2 and $0.1 \%$.

With reference to the contribution to employment, it can be seen that companies based on intellectual property contribute to the creation of approximately $26 \%$ of the total labour force, corresponding to approximately 56 million jobs.

In particular, the companies concentrated on brands offer the most consistent occupational quota (equivalent to $20.8 \%$ ). Companies based on design follow with the creation of jobs (12.2\%); companies based on patents (with a quota of $10.3 \%$ ); copyright-based companies (3.2\%) and, finally, geographic protection-based companies (in the percentage of $0.2 \%)$.

The intensive copyright sector in Italy contributes, however, to the creation of a European GDP of approximately $3.7 \%$ and a quota of employment of approximately $2.4 \%$. In 
this regard, it is important to highlight a coinciding trend between the economic contribution (on a European level of 27 countries) of the Italian intensive copyright industries and of Hungarian industries.

This similarity justifies the fact that, later on, to assess the economic impact of the Italian industries of intensive copyright, with special reference to quantification of the weight of economic activities with partial incidence and support, reference will be made to the criteria adopted by Hungary, based on the average factor and illustrated in the document called "The Economic Contribution of Copyright-Based Industries in Hungary" (WIPO 2005).

Table 1 shows the different methods to assess the economic impact of copyright industries grouped by year and number of countries applying them.

\section{Results and discussion: WIPO vs French model}

Before proceeding with the empirical application of the method elaborated by WIPO in 2003 called "Wipo Guide on surveying the economic contribution of the copyright-based intensive" - hereinafter also referred to as the WIPO method and the model included in the recent French study called "1er Panorama des industries culturelles et créatives. Au couer du rayonnment et de la competitivité de la France"-hereinafter also referred to as the French model, it is important to clarify the following points:

1. the collection of official data related to economic activities included in copyright has been carried out, considering the entire Italian territory;

2. the period in question is the year 2011;

3. the collection of official data related to Italian economic copyright activities has been carried out with access to the official websites of the Central Institution of Statistics-ISTAT, and Europstate of the United Nations Statistic Divisions; and

4. therefore, an empirical observation welcomes the Italian classification for Ateco 2007 activities, including the four digit Ateco codes, up to the fourth figure of detail. These figures are updated to 2011.

\section{The WIPO method}

For purposes related to application of the WIPO method, we have repeated the same criteria of the definition of boundaries for Italian intensive copyright companies in the field of copyright.

As already indicated in the literature analysis, the WIPO definition classifies the copyright industries into four groups:

Table 1 The different methods to asses the economic impact of copyright industries

\begin{tabular}{lll}
\hline Years & Copyright models & \multicolumn{1}{c}{$\begin{array}{l}\text { Number of countries } \\
\text { who apply the model }\end{array}$} \\
\hline 2003 & WIPO Model & 39 countries \\
2008 & European Union Model & 27 countries \\
2013 & French Model & 1 country \\
\hline
\end{tabular}


1. core copyright (press and literature; music; theatrical productions; operas; motion pictures and videos; radio and television; photography; software and databases; visual and graphic arts; advertising service; copyright collecting societies);

2. interdependent copyright (TV sets; radio; VCR's; CD players, DVD players, cassette players, electronic game equipment and other similar equipment; computers and equipment; musical instruments; photographic and cinematographic instruments; photocopiers; blank recording material; paper);

3. partial copyright industries (apparel, textiles and footwear; jewellery and coins; other crafts, furniture; household goods, china and glass; wall finishes and carpets; toys and games; architecture, engineering, surveying; interior design; museums); and

4. non-dedicated support industries (general wholesale and retailing; general transportation; telephony and internet).

In particular, compared with the economic contribution, the WIPO model recognises in the core industries a percentage of $100 \%$ and a variable percentage to the non-core industries (Interdependent, Partial and Non-dedicated). Therefore, in this study, we will assume that the core copyright industries provide a $100 \%$ contribution to the economic impact of copyright. In line with similar studies that follow the WIPO guidelines, the interdependent copyright industries will also be applied the percentage of $100 \%$.

However, the partial and non-dedicated copyright industries will be applied the same percentages of a study carried out in Hungary, that applies the WIPO guidelines called "The economic contribution of copyright industries in Hungary. The 2005 Report", as indicated in Table 2:

Considering all of the above, we have applied the percentages indicated and we have reached the definition of the economic impact of copyright industries in Italy for the year 2011.

Data related to the core copyright industries include, perfectly aligned with the WIPO method, the following activities:

\section{Table 2 The copyright factors}

\begin{tabular}{ll}
\hline Fields with a partial incidence and support & Copyright factors (\%) \\
\hline Partial copyright industries & \\
Apparel, textiles and footwear & 0.50 \\
Jewellery and coins & 25 \\
Other crafts & 40 \\
Furniture & 5 \\
Household goods, china and glass & 0.50 \\
Wall coverings and carpets & 2 \\
Toys and games & 50 \\
Architecture, engineering and surveying & 10 \\
Interior design & 10 \\
Museums & 50 \\
Non-dedicated industries & 5.7 \\
\hline
\end{tabular}


- publishing;

- music;

- productions and theatrical works;

- cinema and video;

- radio and television;

- photography;

- software and database;

- graphic and visual arts;

- publicity services; and

- copyright collection companies.

The added value produced by all of the core copyright industries for the year 2011 amounts to Euro 59,272,249,000, while the total number of employees in this field is approximately $1,071,247$.

Table 3 provides a detailed illustration of each single data. It is important to point out that the collecting companies are now shown in the table as the value of economic activities included in them is zero.

Table 3 immediately shows how the activities with the greatest incidence on the production of added value of the dominion of core copyright are: radio and television, software and databases, publishing, musical productions and theatrical works.

However, with regard to the contribution to employment, we must highlight the industries of publishing, software and databases, music, productions and theatrical works as well as radio and television.

Interdependent industries include the following fields:

- components (TV, radio, CD players, CD's, DVD's, electronic games equipment and other equipment);

Table 3 The economic impact of the core copyright industries in Italy

\begin{tabular}{|c|c|c|c|c|c|c|c|}
\hline Sector & $\begin{array}{l}\text { Number of } \\
\text { companies }\end{array}$ & Turnover & $\begin{array}{l}\text { Production } \\
\text { value }\end{array}$ & $\begin{array}{l}\text { Added value } \\
\text { to the cost } \\
\text { of factors }^{\mathrm{a}}\end{array}$ & $\begin{array}{l}\text { Personnel } \\
\text { costs }^{\mathrm{a}}\end{array}$ & $\begin{array}{l}\text { Wages and } \\
\text { salaries }^{\mathrm{a}}\end{array}$ & $\begin{array}{l}\text { Number } \\
\text { of people } \\
\text { employed }\end{array}$ \\
\hline $\begin{array}{l}\text { Radio and } \\
\text { television }\end{array}$ & 45,369 & $37,542,651$ & $38,056,849$ & $16,762,632$ & $5,178,551$ & $3,776,782$ & 160,097 \\
\hline $\begin{array}{l}\text { Software and } \\
\text { Database }\end{array}$ & 52,060 & $35,958,861$ & $33,114,823$ & $14,099,081$ & $8,960,304$ & $6,472,763$ & 237,840 \\
\hline Publishing & 105,530 & $51,299,695$ & $34,645,888$ & $12,479,961$ & $6,771,733$ & $4,873,563$ & 304,186 \\
\hline $\begin{array}{l}\text { Music, } \\
\text { productions } \\
\text { and theatri- } \\
\text { cal works }\end{array}$ & 48,993 & $36,578,762$ & $22,997,308$ & $7,643,128$ & $3,608,721$ & $2,646,011$ & 163,482 \\
\hline $\begin{array}{c}\text { Graphic and } \\
\text { visual arts }\end{array}$ & 51,730 & $11,629,517$ & $11,660,010$ & $4,174,737$ & $1,874,366$ & $1,371,125$ & 109,868 \\
\hline $\begin{array}{l}\text { Publicity } \\
\text { services }\end{array}$ & 16,141 & $12,245,526$ & $14,027,543$ & $2,028,882$ & $1,192,663$ & 853,549 & 45,966 \\
\hline $\begin{array}{l}\text { Cinema and } \\
\text { video }\end{array}$ & 13,261 & $4,118,446$ & $4,424,108$ & $1,646,773$ & 663,364 & 488,990 & 33,762 \\
\hline Photography & 5,570 & $1,087,352$ & $1,103,091$ & 437,055 & 278,417 & 199,757 & 15,445 \\
\hline Total & 338,654 & $190,460,810$ & $160,029,619$ & $59,272,249$ & $28,528,120$ & $20,682,541$ & $1,071,247$ \\
\hline
\end{tabular}

a Thousands of euro 
- computers and equipment;

- musical instruments;

- photographic and cinema instruments;

- photocopiers;

- recording material; and

- paper.

The added value produced by all of the interdependent copyright industries in Italy for the year 2011 amounts to euro 30,862,379,000 while the number of employees is 621,219 .

Table 4 illustrates each single figure in detail:

With regard to the contribution to the production of added value and the contribution to employment, the industries of photographic and cinema instruments, components and paper stand out from all of the rest.

However, the field of partial incidence industries includes the following sectors:

- clothing, textiles and footwear;

- jewellery and coins;

- other connected activities;

- furniture;

- home objects, porcelain and glass;

- wall coverings and carpets;

- games and toys;

- architecture, engineering;

- interior design; and

- museums.

Partial incidence industries in 2011 in Italy generated an added value of euro $3,695,700,000$, with 89,445 employees.

Table 4 The economic impact of the interdependent copyright industries in Italy

\begin{tabular}{|c|c|c|c|c|c|c|c|}
\hline Sector & $\begin{array}{l}\text { Number of } \\
\text { companies }\end{array}$ & Turnover $^{a}$ & $\begin{array}{l}\text { Production } \\
\text { value }\end{array}$ & $\begin{array}{l}\text { Added } \\
\text { value to cost } \\
\text { of factors }\end{array}$ & $\begin{array}{l}\text { Personnel } \\
\text { costs }\end{array}$ & $\begin{array}{l}\text { Salaries } \\
\text { and wager }\end{array}$ & $\begin{array}{l}\text { Number } \\
\text { of people } \\
\text { employed }\end{array}$ \\
\hline $\begin{array}{r}\text { Photographic } \\
\text { and cinema } \\
\text { instruments }\end{array}$ & $\begin{array}{l}56,864 \\
s\end{array}$ & $36,140,347$ & $19,279,112$ & $7,638,823$ & $3,868,373$ & $2,793,882$ & 175,120 \\
\hline Components & 19,632 & $31,415,007$ & $17,711,714$ & $6,225,957$ & $4,022,386$ & $2,877,166$ & 114,511 \\
\hline Paper & 41,716 & $42,528,443$ & $18,394,615$ & $5,478,866$ & $2,695,126$ & $1,931,585$ & 124,026 \\
\hline Photocopiers & 14,101 & $18,824,547$ & $8,494,869$ & $3,538,999$ & $2,163,194$ & $1,555,161$ & 61,964 \\
\hline $\begin{array}{r}\text { Recording } \\
\text { material }\end{array}$ & 7485 & $15,437,148$ & $12,259,065$ & $3,432,097$ & $1,929,221$ & $1,373,696$ & 51,858 \\
\hline $\begin{array}{l}\text { Musical instru- } \\
\text { ments }\end{array}$ & - 18,767 & $21,435,067$ & $7,852,265$ & $3,167,804$ & $1,745,079$ & $1,257,520$ & 66,885 \\
\hline $\begin{array}{l}\text { Computers } \\
\text { and equip- } \\
\text { ment }\end{array}$ & 7374 & $7,429,031$ & $4,008,316$ & $1,379,832$ & 863,588 & 618,359 & 26,856 \\
\hline Total & 165,939 & $173,209,590$ & $87,999,958$ & $30,862,379$ & $17,286,967$ & $12,417,370$ & 621,219 \\
\hline
\end{tabular}

a Thousands of euro 
Table 5 illustrates each single figure in detail:

After attentive reading we can see how, compared with the production of added value and employment, the industries operating in the field of architecture and engineering, games and toys and furniture, stand out from all of the rest.

Finally, the fields of companies supporting copyright include wholesale and retail industries, transport, telephones and internet.

In Italy, in 2011, the contribution of non-dedicated industries to added value is euro $6,962,219,000$ with 156,563 employees.

It is important to point out that the copyright factor identified for this field is $5.7 \%$; considering this, Table 6 indicates the turnover of industries supporting copyright in Italy for the year 2011.

\section{The French method}

Subsequently, in line with the objective of this contribution, an estimate has been made of the value of the economic impact of copyright industries in Italy with the alternative method, based on recent research carried out in France by the company Ernst \& Young called "1 Panorama des Industries Culturelles et Créatives, Au Couer du Rayonnement et de la Competitivitè de la France".

In particular, the French study carried out in 2013 has been re-proposed to the Italian industrial system, that classifies the copyright dominion into nine sectors: graphic and plastic arts; music; live entertainment; cinema, television, radio, videogames, books, press.

Table 5 - The economic impact of the partial incidence copyright industries in Italy

\begin{tabular}{|c|c|c|c|c|c|c|c|}
\hline Sector & $\begin{array}{l}\text { Number } \\
\text { of companies }\end{array}$ & Turnover ${ }^{a}$ & $\begin{array}{l}\text { Production } \\
\text { value }\end{array}$ & $\begin{array}{l}\text { Added value } \\
\text { to the cost } \\
\text { of factors }\end{array}$ & $\begin{array}{l}\text { Personnel } \\
\text { costs }\end{array}$ & $\begin{array}{l}\text { Salaries } \\
\text { and wages }\end{array}$ & $\begin{array}{l}\text { Number } \\
\text { of people } \\
\text { employed }\end{array}$ \\
\hline $\begin{array}{l}\text { Architecture } \\
\text { and engi- } \\
\text { neering }\end{array}$ & 21,544 & $1,876,842$ & $2,124,165$ & $1,076,572$ & 287,613 & 208,886 & 28,538 \\
\hline $\begin{array}{l}\text { Games and } \\
\text { toys }\end{array}$ & 5612 & $5,313,074$ & $3,205,369$ & $1,044,905$ & 572,781 & 413,653 & 21,285 \\
\hline Furniture & 1428 & $2,780,670$ & $2,702,958$ & 722,858 & 518,269 & 359,889 & 14,930 \\
\hline Interior Design & 3289 & 990,919 & 988,058 & 334,827 & 162,178 & 118,498 & 8,263 \\
\hline $\begin{array}{l}\text { Other con- } \\
\text { nected } \\
\text { activities }\end{array}$ & 3072 & 771,844 & 301,171 & 153,834 & 71,345 & 52,040 & 6666 \\
\hline $\begin{array}{l}\text { Clothing, } \\
\text { textiles and } \\
\text { footwear }\end{array}$ & 627 & 475,652 & 385,703 & 109,543 & 68,207 & 49,222 & 3044 \\
\hline Museums & 185 & 169,033 & 181,963 & 88,344 & 80,436 & 58,376 & 3015 \\
\hline $\begin{array}{c}\text { Wall coverings } \\
\text { and carpets }\end{array}$ & 316 & 292,945 & 268,588 & 76,428 & 44,729 & 32,064 & 1625 \\
\hline $\begin{array}{l}\text { Home objects, } \\
\text { porcelain } \\
\text { and glass }\end{array}$ & 211 & 239,199 & 219,796 & 67,572 & 42,323 & 30,146 & 1435 \\
\hline $\begin{array}{l}\text { Jewellery and } \\
\text { coins }\end{array}$ & 192 & 113,934 & 66,547 & 20,817 & 12,061 & 8879 & 645 \\
\hline Total 3 & 36,477 & $13,024,111$ & $10,444,318$ & $3,695,700$ & $1,859,942$ & $1,311,651$ & 89,445 \\
\hline
\end{tabular}

a Thousands of euro 
Table 6 The economic impact of the supporting copyright industries in Italy

\begin{tabular}{llllllll}
\hline Sector & $\begin{array}{l}\text { Number of } \\
\text { companies }\end{array}$ & Turnover & $\begin{array}{l}\text { Production } \\
\text { value }\end{array}$ & $\begin{array}{l}\text { Added value } \\
\text { to the cost } \\
\text { of factors }\end{array}$ & $\begin{array}{l}\text { Personnel } \\
\text { costs }\end{array}$ & $\begin{array}{l}\text { Salaries } \\
\text { and wages }\end{array}$ & $\begin{array}{l}\text { Number } \\
\text { of people } \\
\text { employed }\end{array}$ \\
\hline $\begin{array}{c}\text { Support } \\
\text { copyright } \\
\text { industries }\end{array}$ & 43,420 & $27,372,933$ & $17,629,162$ & $6,962,219$ & $3,788,173$ & $2,775,210$ & 156,563 \\
\begin{tabular}{c} 
Total \\
\hline
\end{tabular} & 43,420 & $27,372,933$ & $17,629,162$ & $6,962,219$ & $3,788,173$ & $2,775,210$ & 156,563 \\
\hline
\end{tabular}

In order to apply the methodology of the French model to the industrial reality of Italian copyright, some adjustments have been made: in particular, the Ateco 2007 economic activities have been classified into six groups:

(a) visual arts, music and live entertainment;

(b) cinema, film and video;

(c) radio;

(d) television;

(e) videogames; and

(f) books, press, newspaper and magazines.

For an estimate of contribution to added value and employment, each one of the six sectors has been divided up even further into direct and connected activities. Here below a description of the activities included in each sector is provided together with clarifications on the activities considered direct and the ones considered connected. The method with which the distinction between direct and indirect activities has been performed, in general terms, has been inherited from the French study.

(a) In our study the field of visual arts coincides with the definition provided by the

French study, excluding subsidies by the Government. To be more precise, the field of visual arts includes artistic and professional activities; they also include proceeds of authors of visual arts (painters, sculptors, graphics), craftsmen and employees belonging to the field of art. Furthermore, it also includes activities of architects, design, photographers, art merchants as well as proceeds deriving from museums.

However, the sale of material for professional photography, activities connected with the organisation of art fairs and exhibitions, the sale of art books and comics and copies for private use are all considered as connected activities.

In the field of music the following are attributed: the sale of recorded music, proceeds from phonographic and music editors, activities related to music entertainment (contemporary and classical) as well as television, radio and disco activities with regards to the diffusion of music. Activities related to sector exportation and costs related to public teaching of music in conservatories are considered as direct.

However, connected activities are considered those deriving from the market of instrument and accessories for the sector, the sale of audio material, proceeds from specialised 
musical publications, activities related to copyrights on connected markets and contributions to private copies through connected supports.

Finally, the field of live entertainment (in line with the methodological definition of the French study) includes activities related to live entertainment (dance, theatre, music, circus arts) as direct activities and all services generated from live entertainment (consumptions, accommodation, other tourist related services and bookings etc.) as connected activities.

Table 7 illustrates in detail all data related to the sector of visual arts, music, live entertainment according to the number of companies, turnover, added value and number of employees.

(b) The field of cinema, in line with the definition of the French study, includes proceeds from cinemas, pre-sales and co-productions of TV channels, as well as the contributions provided by foreign co-producers and proceeds from publicity and sales for export.

The sale and hiring of films in DVD-Blu-Ray and activities related to video-on-demand are included.

In particular, activities related to specialised cinema press, the production and sale of video equipment and material are considered connected. Furthermore, proceeds related to the sale of copies for private use through smartphones and tablets are included.

Table 8 illustrates, in detail, all data related to the sector of cinemas according to the number of companies, turnover, added value and the number of employees.

(c) The radio sector, in accordance with the French study, is attributed in a direct manner, all publicity proceeds and contributions provided to the public audio-visual field; however, indirectly, the sale of audio material. Furthermore, for Italy all activities deriving from satellite telecommunications and from other telecommunications are included.

Table 9 below illustrates in detail all data related to the field of radio according to the number of companies, turnover, added value and the number of employees.

(d) In the field of television, in the definition of the French study, proceeds from TV channels, the sale and hiring of DVD's in Blu-Ray and video-on-demand as well as sales related to sector exports, are attributed. To repeat the study in Italy, satellite tele-

Table 7 The economic impact of the sector of visual art, music and live entertainment

\begin{tabular}{|c|c|c|c|c|c|c|c|}
\hline $\begin{array}{l}\text { Visual arts, } \\
\text { music, live } \\
\text { entertain- } \\
\text { ment }\end{array}$ & $\begin{array}{l}\text { Number of } \\
\text { companies }\end{array}$ & Turnover $^{\mathbf{a}}$ & $\begin{array}{l}\text { Production } \\
\text { value }^{a}\end{array}$ & $\begin{array}{l}\text { Added value } \\
\text { to the cost } \\
\text { of factors }\end{array}$ & $\begin{array}{l}\text { Personnel } \\
\text { costs }^{a}\end{array}$ & $\begin{array}{l}\text { Salaries } \\
\text { and } \\
\text { wages }^{\text {a }}\end{array}$ & $\begin{array}{l}\text { Number } \\
\text { of people } \\
\text { employed }\end{array}$ \\
\hline Direct & 362,531 & $39,185,175$ & $41,548,314$ & $19,621,607$ & $6,488,051$ & $4,740,610$ & 545,549 \\
\hline Connected & 422,984 & $260,702,301$ & $170,506,795$ & $54,712,144$ & $32,333,176$ & $23,341,994$ & $1,568,588$ \\
\hline Total & 785,515 & $299,887,475$ & $212,055,108$ & $74,333,751$ & $38,821,227$ & $28,082,604$ & $2,114,137$ \\
\hline
\end{tabular}

a Thousands of euro 
Table 8 The economic impact of the sector of cinema

\begin{tabular}{|c|c|c|c|c|c|c|c|}
\hline Cinema & $\begin{array}{l}\text { Number } \\
\text { of companies }\end{array}$ & Turnover $^{\mathrm{a}}$ & $\begin{array}{l}\text { Production } \\
\text { value }^{a}\end{array}$ & $\begin{array}{l}\text { Added value } \\
\text { to the cost } \\
\text { of factors }^{a}\end{array}$ & $\begin{array}{l}\text { Personnel } \\
\text { costs }^{a}\end{array}$ & $\begin{array}{l}\text { Wages and } \\
\text { salaries }^{\mathbf{a}}\end{array}$ & $\begin{array}{l}\text { Number } \\
\text { of people } \\
\text { employed }\end{array}$ \\
\hline Direct & 18,075 & $6,815,082$ & $7,018,212$ & $1,924,228$ & 886,305 & 649,315 & 44,267 \\
\hline Connected & 23,442 & $17,250,692$ & $10,741,990$ & $3,554,977$ & $2,056,729$ & $1,483,671$ & 80,329 \\
\hline Total & 41,517 & $24,065,773$ & $17,760,203$ & $5,479,205$ & $2,943,079$ & $2,132,986$ & 124,595 \\
\hline
\end{tabular}

a Thousands of euro

Table 9 The economic impact of the sector of radio

\begin{tabular}{|c|c|c|c|c|c|c|c|}
\hline Radio & $\begin{array}{l}\text { Number } \\
\text { of companies }\end{array}$ & Turnover $^{a}$ & $\begin{array}{l}\text { Production } \\
\text { value }^{a}\end{array}$ & $\begin{array}{l}\text { Added value } \\
\text { to the cost } \\
\text { of factors }\end{array}$ & $\begin{array}{l}\text { Personnel } \\
\text { costs }^{a}\end{array}$ & $\begin{array}{l}\text { Salaries } \\
\text { and wages }\end{array}$ & $\begin{array}{l}\text { Number } \\
\text { of people } \\
\text { employed }\end{array}$ \\
\hline Direct & 13,472 & $7,034,298$ & $7,519,407$ & $1,917,310$ & $1,097,377$ & 802,019 & 44,416 \\
\hline Connected & 9,842 & $14,025,070$ & $7,620,247$ & $2,593,981$ & $1,819,527$ & $1,307,605$ & 51,989 \\
\hline Total & 23,135 & $21,059,368$ & $15,139,654$ & $4,511,290$ & $2,916,904$ & $2,109,623$ & 96,405 \\
\hline
\end{tabular}

a Thousands of euro

communication activities and other telecommunication activities have been included. However, activities with a connected impact include satellite telecommunications and other telecommunication activities.

Table 10 illustrates in detail all data related to the field of television according to the number of companies, turnover, added value and the number of employees.

(e) In the methodological definition of the French study, the field of videogames includes games for game halls, lap tops, on-line, for computers, for mobile phones and for exportation of videogames. However, proceeds deriving from the sale of components for videogames are included in a connected manner.

Table 11 below illustrates in detail all data related to the sector of videogames according to the number of companies, turnover, added value and the number of employees.

(f) An analysis of the economic impact of the fields of books, press, newspapers and magazines for Italy generally follows the definition of the French study. In particular, the sector of books may be attributed the edition and sale of printed and digital

Table 10 The economic impact of the sector of television

\begin{tabular}{|c|c|c|c|c|c|c|c|}
\hline Television & $\begin{array}{l}\text { Number } \\
\text { of companies }\end{array}$ & Turnover $^{\mathrm{a}}$ & $\begin{array}{l}\text { Production } \\
\text { value }^{a}\end{array}$ & $\begin{array}{l}\text { Added value } \\
\text { to the cost } \\
\text { of factors }\end{array}$ & $\begin{array}{l}\text { Personnel } \\
\text { costs }^{a}\end{array}$ & $\begin{array}{l}\text { Salaries } \\
\text { and wages }^{a}\end{array}$ & $\begin{array}{l}\text { Number } \\
\text { of people } \\
\text { employed }\end{array}$ \\
\hline Direct & 16,347 & $18,158,636$ & $19,204,580$ & $6,192,948$ & $3,065,847$ & $2,216,466$ & 79,830 \\
\hline Connected & 29,349 & $22,585,592$ & $15,089,735$ & 4,974,057 & $3,021,518$ & $2,184,276$ & 109,055 \\
\hline Total & 45,696 & $40,744,228$ & $34,249,315$ & $11,167,006$ & $6,087,365$ & $4,400,742$ & 188,885 \\
\hline
\end{tabular}

a Thousands of euro 
Table 11 The economic impact of the sector of videogames

\begin{tabular}{|c|c|c|c|c|c|c|c|}
\hline Videogames & $\begin{array}{l}\text { Number of } \\
\text { companies }\end{array}$ & Turnover ${ }^{a}$ & $\begin{array}{l}\text { Production } \\
\text { value }^{\mathrm{a}}\end{array}$ & $\begin{array}{l}\text { Added value } \\
\text { to the cost } \\
\text { of factors }\end{array}$ & $\begin{array}{l}\text { Personnel } \\
\text { costs }^{a}\end{array}$ & $\begin{array}{l}\text { Salaries } \\
\text { and wages }\end{array}$ & $\begin{array}{l}\text { Number } \\
\text { of people } \\
\text { employed }\end{array}$ \\
\hline Direct & 23,744 & $13,356,963$ & $7,973,288$ & $2,899,614$ & $1,690,010$ & $1,234,768$ & 79,260 \\
\hline Connected & 41,623 & $33,041,339$ & $29,487,985$ & $14,369,308$ & $9,370,129$ & $6,766,894$ & 225,021 \\
\hline Total & 65,3676 & $46,389,302$ & $37,461,273$ & $17,268,922$ & $11,060,140$ & $8,001,662$ & 304,281 \\
\hline
\end{tabular}

a Thousands of euro

books, sales related to exports while, in an indirect form, the sale of digital reading supports of magazines and newspapers have been considered.

This group has allowed for an estimation, in Italy, of the added value per field in euro 15,241,248,000, euro 11,730,762,000 of which of direct added value and euro $3,510,486,000$ of connected added value. The number of employees, however, generally amounted to 300,156 , of which 235,423 employees belong to direct economic activities and 64,733 employees in connected economic activities.

Table 12 illustrates in detail all data of the sector in question.

Application of the French method allows for the implementation of a classification of the Italian production activities compared with the contribution of added value and the occupational offer.

Table 13 in a decreasing order, summarises the estimates of Italian copyright companies for the year 2011.

Application of the French model to Italian intensive copyright industries allows us to conclude that the total number of employees, for 2011 , is $3,128,458$, while the total added value produced is equivalent to euro $128,001,422,000$.

As a percentage, the added value of intensive copyright industries corresponds to approximately $8.1 \%$ of the Gross Domestic Product.

\section{Conclusions}

The study carried out allows us to reach a whole range of conclusions.

Initially, the current importance of copyright in the economy of knowledge has been highlighted. However, as seen, from an economic point of view, the analysis carried out by the field of copyright needs to measure the economic impact on the reference system, in line, with international trends.

Based on these theoretical premises (with the obligation to provide a summary and without the pretention of being exhaustive), reference is made to the main best practices

Table 12 The economic impact of the sector of books, press, newspapers and magazines

\begin{tabular}{|c|c|c|c|c|c|c|c|}
\hline $\begin{array}{l}\text { Books, press, } \\
\text { newspapers, } \\
\text { magazines }\end{array}$ & $\begin{array}{l}\text { Number of } \\
\text { companies }\end{array}$ & Turnover $^{a}$ & $\begin{array}{l}\text { Production } \\
\text { value }^{\mathrm{a}}\end{array}$ & $\begin{array}{l}\text { Added value } \\
\text { to the cost } \\
\text { of factors }\end{array}$ & $\begin{array}{l}\text { Personnel } \\
\text { costs }^{a}\end{array}$ & $\begin{array}{l}\text { Salaries } \\
\text { and wages }\end{array}$ & $\begin{array}{l}\text { Number } \\
\text { of people } \\
\text { employed }\end{array}$ \\
\hline Direct & 53,865 & $52,688,627$ & $43,342,968$ & $11,730,762$ & $7,342,094$ & $5,205,082$ & 235,423 \\
\hline Connected & 22,225 & $13,625,625$ & $10,650,998$ & $3,510,486$ & $1,565,815$ & $1,141,954$ & 64,733 \\
\hline Total & 76,091 & $66,314,252$ & $53,993,966$ & $15,241,248$ & $8,907,910$ & $6,347,036$ & 300,156 \\
\hline
\end{tabular}

a Thousands of euro 
Table 13 The economic impact of the Italian copyright companies

\begin{tabular}{|c|c|c|c|c|c|c|c|}
\hline Sector & $\begin{array}{l}\text { Number of } \\
\text { companies }\end{array}$ & Turnover $^{a}$ & $\begin{array}{l}\text { Production } \\
\text { value }^{a}\end{array}$ & $\begin{array}{l}\text { Added value } \\
\text { to the cost } \\
\text { of factors }^{\mathrm{a}}\end{array}$ & $\begin{array}{l}\text { Personnel } \\
\text { costs }^{\mathrm{a}}\end{array}$ & $\begin{array}{l}\text { Salaries } \\
\text { and } \\
\text { wages }^{\mathbf{a}}\end{array}$ & $\begin{array}{l}\text { Number } \\
\text { of people } \\
\text { employed }\end{array}$ \\
\hline $\begin{array}{l}\text { Visual arts, } \\
\text { music, live } \\
\text { entertain- } \\
\text { ment }\end{array}$ & 785,515 & $299,887,475$ & $212,055,108$ & $74,333,751$ & $38,821,227$ & $28,082,604$ & $2,114,137$ \\
\hline $\begin{array}{l}\text { Books, press, } \\
\text { newspapers } \\
\text { and maga- } \\
\text { zines }\end{array}$ & 76,091 & $66,314,252$ & $53,993,966$ & $15,241,248$ & $8,907,910$ & $6,347,036$ & 300,156 \\
\hline Videogames & 65,367 & $46,398,302$ & $37,461,273$ & $17,268,922$ & $11,060,140$ & $8,001,662$ & 304,281 \\
\hline Television & 45,696 & $40,744,228$ & $34,294,315$ & $11,167,006$ & $6,087,365$ & $4,400,742$ & 188,885 \\
\hline Cinema & 41,517 & $24,065,773$ & $17,760,203$ & $5,479,205$ & $2,943,079$ & $2,132,986$ & 124,595 \\
\hline Radio & 23,315 & $21,059,368$ & $15,139,654$ & $4,511,290$ & $2,916,904$ & $2,109,623$ & 96,405 \\
\hline Total & $1,037,500$ & $498,469,399$ & $370,704,519$ & $128,001,422$ & $70,736,625$ & $51,074,654$ & $3,128,458$ \\
\hline
\end{tabular}

a Thousands of euro

that currently exist with which it is possible to measure the economic contribution of intensive copyright industries.

However, as is clearly known, each quantity-related method can only be tested in practice.

Therefore, in the last part of the study, we have carried out the empirical application of the two methods indicated for an estimate of the economic impact of intensive copyright industries in Italy.

In particular, we have decided to repeat the Wipo method and, subsequently, a recent method elaborated in France by the company Ernst \& Young.

From the empirical application of the two methods, it can be seen that the added value of Italian copyright industries for the year 2011 is equivalent to euro 100,792,546,000 on the basis of the WIPO method, against the euro 128,001,442,000 resulting from application of the French model.

Therefore, a difference between the two methods can be seen of approximately euro $27,208,896,000$. An estimate of the number of employees in Italian copyright-intensive industries in 2011, according to the WIPO layout, is approximately 1,938,473 against 3,128,458 employees deriving from application of the French model.

Therefore, a difference can be found between the two methods of approximately $1,189,985$ jobs. In each case, both results allow for the appreciation of the current contribution of the copyright industries in the Italian economy and this information may turn out to be useful in the context of reorganisation of the copyright legislation, or in investment policies and occupational policies on a macroeconomic level. However, the differences in quantities focus attention on the random nature of the methods in question.

The results of our analysis show that the copyright industries have a great impact on the aspects related to the economic growth, labour market and country development.

This job also will support the existing literature on the economic impact of copyright by analysing this issue in the Italian setting. To the best of our knowledge, only a handful of studies have explored the economic impact of copyright industries in Italy. However, this study suffers from many limitations. The first limitation lies in the fact that the 
analysis has been confined to 1 year only. Second, the study suffers from the inherent limitations of the WIPO and French methods.

Considering all the above, future research directions should include extending the time horizon of the analysis as well as devising an experimental method to assess the economic impact of copyright-intensive industries.

\section{Methods}

The research utilises a multi-method approach based on a qualitative and quantitative investigation, with the aim to assess the economic impact of copyright-based industries in Italy.

The analysis is structured on two levels. In the first level, we analyse the international best practice used for the evaluation of the economic impact of copyright-intensive industries. In the second level, by utilising a quantitative method, we try to measure the economic performance of copyright-intensive industries with reference to Italy.

The year selected for the survey is 2011 , since it is the most recent year with comprehensive data.

In order to assess the economic impact of copyright-based industries, the study adopts WIPO's guidelines “Wipo Guide on surveying the Economic Contribution of the Copyright-Based Industries" and the Ernest \& Young study entitled: "1 1 r Panorama des Industries Culturelles et Créatives. Au Couer du Rayonnement et de la Competitivité de la France."

The main source data are statistic databases such as Istat, Eurostat and United Nations Statistics Division. The industrial classification starts with the International Standard Industrial Classification (ISIC) suggested in the WIPO Guide and, after the conversion, first in NACE and then in ATECO 2007, we identify the industries and their activities as relevant to copyright-based industries in Italy.

The activities and industries which produce creations protected under copyright law and the industries that utilise such products are important economic factors that should be assessed as they generate value added.

The methodological guide published by WIPO defines also four industry categories and a different impact of them.

These four industries are core copyright industries, interdependent copyright industries, partial copyright industries and non-dedicated support industries.

Authors' contributions

SM: Industry level analysis report: European Union; Result and discussion (the French Method). FN: Method; Result and discussion (the Wipo Method). FR: Introduction; Conclusion. MM: Literature Review; Literature Review Wipo Method;

Literature Review French Method. All authors read and approved the final manuscript.

Author details

1 Department of Economics and Law, University of Cassino and Southern Lazio, Via Sant'Angelo, 03043 Cassino, FR, Italy.

2 Business Management, University of Rome "Link Campus", Via Nomentana, 335, 00162 Rome, Italy.

Competing interests

The authors declare that they have no competing interests.

Received: 6 November 2015 Accepted: 30 December 2015

Published online: 03 February 2016 


\section{References}

Allen Consulting Group (2001) The Economic Contribution of Australia's Copyright Industries, Australian Copyright Council and Centre for Copyright Studies

Barrowclough D, Kozul-Wright Z (2008) Creative industries and developing countries. Routledge, New York

Carayannis EG (ed) (2006) Knowledge creation, diffusion and use in innovation networks e knowledge clusters. Praeger, London

Carayannis EG (2009) Firm evolution dynamics: toward sustainable entrepreneurship and robust competitiveness in the knowledge economy and society. Int I Innov Reg Dev 1(3):235-254

Carayannis EG, Campbell DF (2011) Open innovation diplomacy and a 21st century fractal research, education and innovation (FREIE) ecosystem: building on the quadruple and quintuple helix innovation concepts and the "mode 3 " knowledge production system. J Knowl Econ 2(3):327-372

Chase RL (1997) The knowledge-based organization: an international survey. J Knowl Manag 1(1):38-49

Chow KB, Leo KM (2005) The economic contribution of copyright based industries in Singapore. Rev Econ Res Copyr Issues 2(2):127-148

Del Giudice M, Della Peruta M, Maggioni V (2013) Collective knowledge and organizational routines within academic communities of practice: an empirical research on science-entrepreneurs. J Knowl Econ 4(3):260-278

Dudareva K (2013) Strong copyright protection versus development: comparative legal and economic analysis of copyright infringement in the US, the EU and Ukraine

Gantchev D (2004) The WIPO guide on surveying the economic contribution of the copyright industries. Rev Econ Res Copyr Issues 1(1):5-16

Hummel M (1989) The Economic Importance of Copyright in The Federal Republic of Germany. Institu für Wirtschafts for schung, Munich

Idris K (2003) Intellectual property: a power tool for economic growth. WIPO Publication 888, Geneva

Lessig L (2004) Free Culture: how big media uses technology and the law to lock down culture and control creativity. Penguin Group, NY

Park WG (2010) The copyright dilemma: copyright systems, innovation and economic development. J Int Aff 64(1):53-68

Picard RG, Toivonen T (2004) Issues in Assessment of the Economic Impact of Copyright. Rev Econ Res Copyr Issues 1(1):20-29

Price T (1989) The Economic Importance of Copyright. Common Law Institute of Intellectual Property, London

Scheuch F, Holzmüller H (1989) Die wirtschaftliche Bedeutung des Urheberrechts in Österreich. Die Wertschöpfung der Copyright-Industries

Siwe S, Mosteller G (1999) Copyright Industries in the U.S. Economy, The 1998 Report, Washington D.C., International Intellectual Property Alliance

Siwek SE (2004) The Measurement of "Copyright"Industries: The US Experience. Rev Econ Res Copyr Issues 1(1):17-25

Towse R (2010) Creativity copyright and the creative industries paradigm. Kyklos 63(3):461-478

Van Der Noll R, Poort J (2011) Assessing the economic contribution of the copyright-based industries remarks and alternatives. SEO-Report nr. 2010-63

Watt R (2013) An empirical analysis of the economics of copyright: how valid are the results of studies in developed countries? WIPO

World Intellectual Property Organization-WIPO (2005) The economic contribution of copyright-based industries in Hungary

\section{Submit your manuscript to a SpringerOpen ${ }^{\circ}$ journal and benefit from:}

- Convenient online submission

- Rigorous peer review

- Immediate publication on acceptance

- Open access: articles freely available online

- High visibility within the field

- Retaining the copyright to your article

Submit your next manuscript at $\mathbf{s p r i n g e r o p e n . c o m ~}$ 